\title{
DAMPAK GLOBALISASI TERHADAP KETIMPANGAN WILAYAH: STUDI DI TUJUH NEGARA ASEAN
}

\author{
THE IMPACT OF GLOBALIZATION ON INEQUALTY: \\ A CASE STUDY OF SEVEN ASEAN COUNTRIES
}

\author{
Sugeng Setyadi \\ Jurusan Ekonomi Studi Pembangunan, Fakultas Ekonomi dan Bisnis \\ Universitas Sultan Ageng Tirtayasa \\ Jl. Raya Jakarta KM. 04. Pakupatan Serang. \\ E-mail: sugeng.setyadi@untirta.ac.id
}

\begin{abstract}
ABSTRAK
Makalah ini menguji hubungan antara globalisasi ekonomi dan tingkat ketimpangan wilayah di negara-negara anggota ASEAN, menggunakan data panel dari tahun 2000 sampai 2012. Hasil penelitian ini menunjukkan pengaruh positif dan signifikan secara statistik antara globalisasi ekonomi terhadap tingkat kesenjangan di negara anggota ASEAN. Negara dengan tingkat integrasi ekonomi lebih besar dengan negara ASEAN cenderung tercatat dengan tingkat ketimpangan wilayah yang lebih tinggi. Temuan ini juga memasukkan variabel penjelas lain yang hubungan yang relevan terhadap ketimpangan spasial yang terjadi di negara ASEAN. Analisis ini juga mengungkapkan secara spasial dampak globalisasi ekonomi terhadap negara dengan populasi penduduk yang lebih besar yang menunjukkan tingkat disparitas wilayah negara-negara ASEAN.
\end{abstract}

Kata kunci: Tingkat Ketimpangan Wilayah, Globalisasi Ekonomi

\section{ABSTRACT}

This paper examines the relationship between economic globalization and inequality in ASEAN member countries, using panel data from 2000-2012. The study showed positive and statistically significant interrelation between economic globalization and inequality in ASEAN member countries. Countries with a greater degree of economic integration with ASEAN countries tend to have the higher level of inequality. The findings also incorporate other explanatory variables that are relevant to measure of spatial inequality. This analysis also revealed the spatial impact of economic globalization on ASEAN countries with larger population that show greater disparity.

Keywords: Regional Inequality, Economic Globalization 


\section{PENDAHULUAN}

Adanya komitmen bersama Masyarakat Ekonomi ASIAN (MEA) di Wilayah ASEAN menunjukkan tidak ada lagi batas dan halangan antar negara anggota dengan integrasi pasar dan produksi, dengan bebasnya pergerakan barang, jasa, investasi, skill tenaga kerja serta bebas modal masuk (freer flow of capital) (Austria, 2012). Hal ini akan berdampak baik positif maupun negatif terhadap pelaksanaan komitmen bersama ini. Komitmen bersamaa ini imbas dari globalisasi ekonomi yang telah dilaksanakan oleh negara-negara maju sejak perang dunia II, yaitu terbentuknya Bank Dunia, Dana Moneter Internasional (IMF), dan Organisasi Perdagangan Dunia (WTO). Untuk dampak positf tidaklah menjadi soal, namun dampak negatif yang muncul dari adanya perjanjian ini yang harus disikapi oleh negara-negara di kawasan ASEAN seperti tingkat ketimpangan yang terjadi di kawasan ASEAN akan menyebabkan ketidakadilan ekonomi yang berujung pada tidak terwujudnya kemakmuran akibat dari dampak globalisasi ekonomi.

Globalisasi ekonomi seperti yang disampaikan oleh (Dreher, 2006) berdampak penting tehadap tingkat kesenjangan wilayah, adapun indikator yang digunakan adalah KOF yaitu indek globalisasi yang dibentuk dan telah di perbaharui oleh (Dreher, Gaston, et all, 2008). Secara keseluruhan indeks globalisasi terdiri dari berbagai aspek sosial, ekonomi dan politik dalam integrasi ekonomi yang tepat digunakan dalam perspektif kebijakan, sebagai jawaban atas keraguan indikator

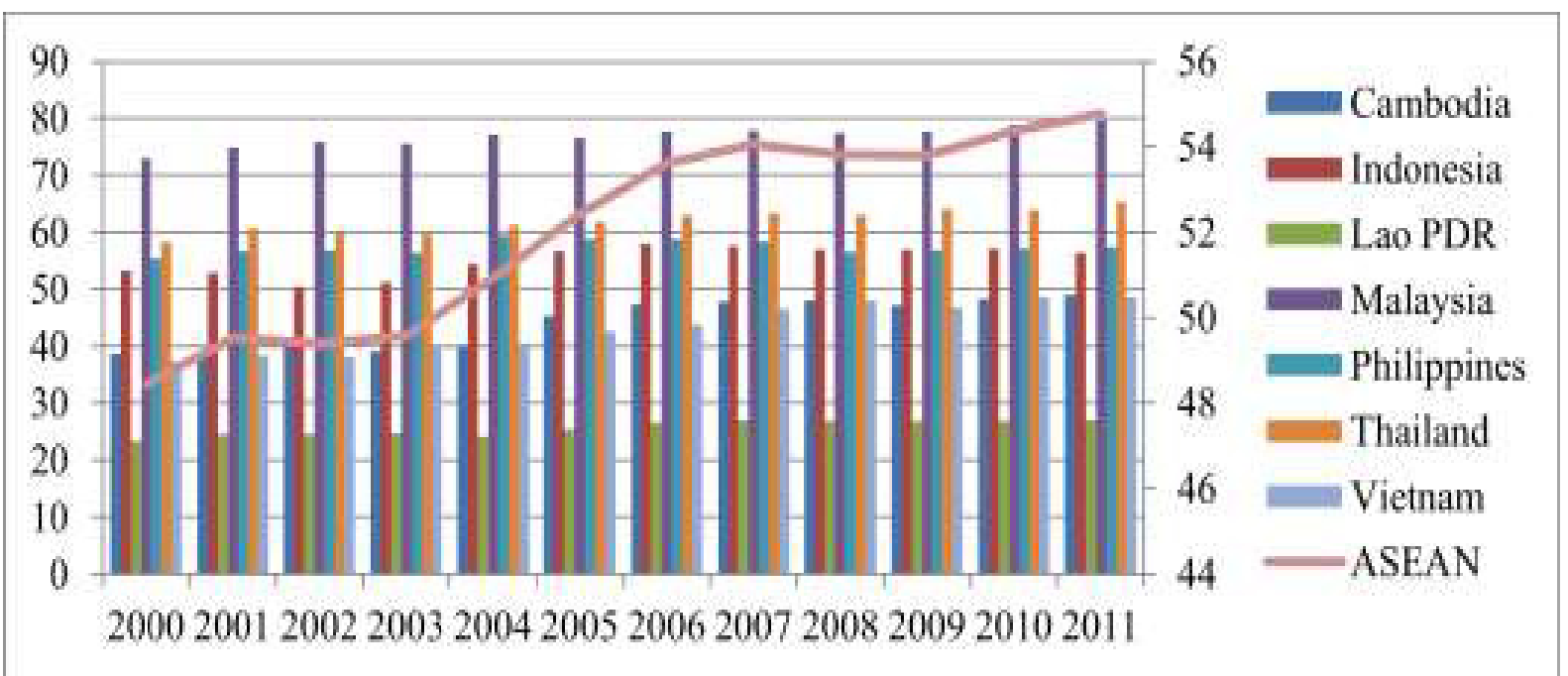

Gambar.1 Perkembangan Indeks Globalisasi di Negara-negara ASEAN pada Tahun 2000 Sumber: http://globalization.kof.ethz.ch/0-2012 


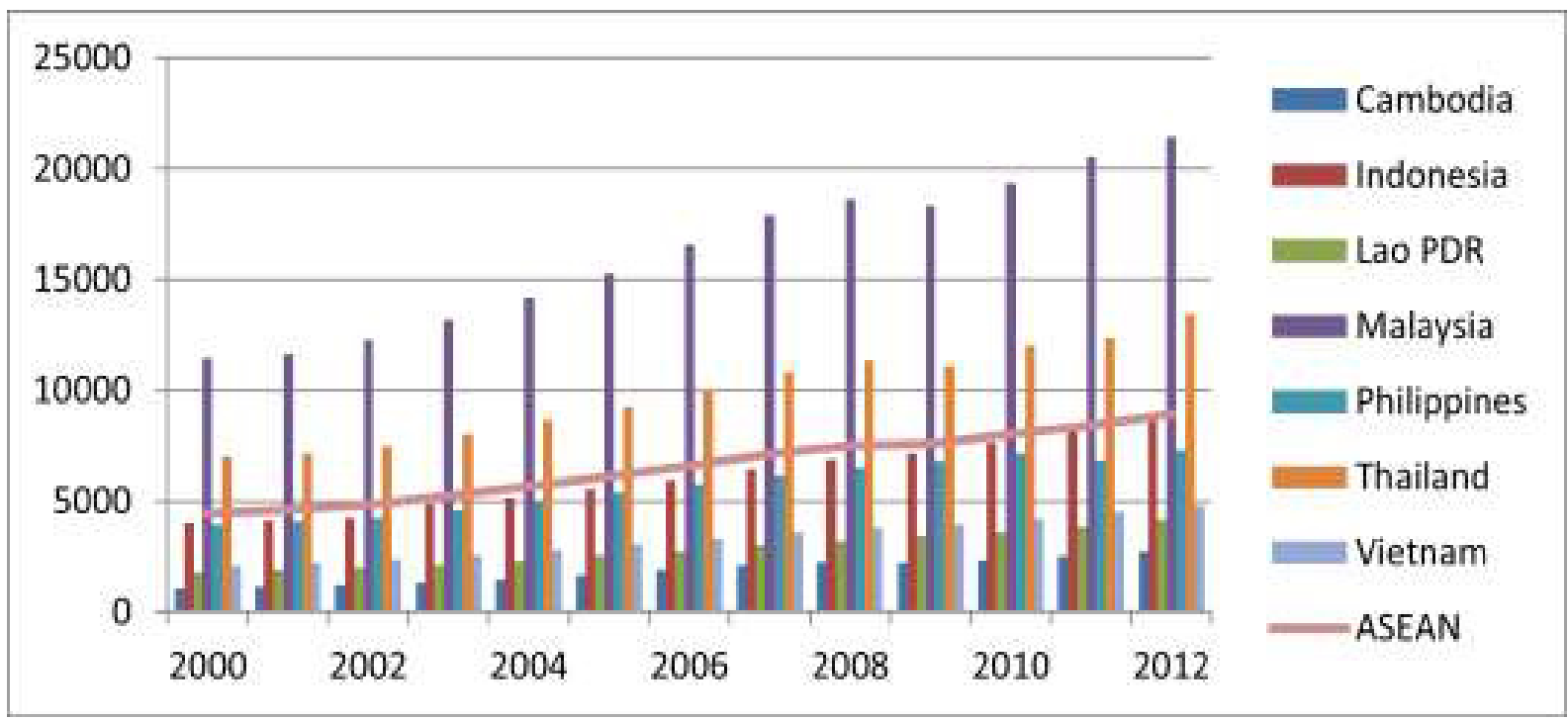

Gambar.2 Perkembangan Pendapatan Per kapita Negara-negara ASEAN pada Tahun 2000- 2012. [Sumber: WDI (World Development Indicators), 2014]

keterbukaan ekonomi dan investasi langsung luar negeri yang biasa digunakan untuk menganalisis hubungan antara ketimpangan dan globalisasi ekonomi (Bank Dunia, 2008). Gambaran mengenai perkembangan globalisasi di kawasan ASEAN disajikan pada Gambar 1. Rata-rata trend dari perkembangan cenderung positif dimana indeks globalisasi ekonomi yang mengalami peningkatan yang cukup signifikan 48,44 pada tahun 2000 dan sebesar 54,77 pada tahun 2011. Indek globalisasi tertinggi adalah negara Malaysia dengan rata-rata indeks sebesar 76,85 dan terendah adalah negara Laos dengan indeks rata-rata sebesar 25,67 dari tahun 2000-2012.

Disisi lain, perkembangan pendapatan per kapita negara-negara ASEAN masih menunjukkan adanya perbedaan yang cukup mencolok, ini bisa dilihat pada gambar 2, sejalan dengan perkembangan indeks globalisasi ekonomi, Malaysia menjadi negara ASEAN dengan tingkat pendapatan per kapita tertinggi dibandingakan dengan negara-negara ASEAN lainnya yang penulis teliti.

Perkembangan rata-rata pendapatan per kapita selama periode tahun 2000-2012 adalah Malaysia sebesar 16210 USD, Thailand sebesar 9896.92 USD, Indonesia sebesar 6070.77 USD, Philipina sebesar 5669.54 USD, Vietnam 3325.38 USD, Laos sebesar 2812.31 USD dan Kamboja sebesar 1835.38 USD. Walaupun secara keseluruhan rata-rata pendapatan per kapita di negara-negara ASEAN mengalami peningkatan sebesar 4467.14 USD pada tahun 2000 menjadi 8934.29 USD pada tahun 2012. Namun, 
masih menunjukkan terdapatnya perbedaan (gap) tingkat pendapatan per kapita yang cukup besar di kawasan ASEAN.

Makalah ini bertujuan untuk meneliti dampak globalisai ekonomi terhadap tingkat kesenjangan pendapatan di negara-negara anggota ASEAN. Penelitian ini juga menggunakan variabel penjelas lain seperti tingkat perndapatan per kapita dan jumlah penduduk secara panel mempengaruhi tingkat ketimpangan penadapatan di Kawasan ASEAN. Sistematika penulisan makalah ini adalah setelah pendahuluan ini, bagian 2 menyajikan kajian teoritis dan literatur yang secara empirik menunjukakn korelasi antara globalisasi ekonomi dengan tingkat kesenjangan. Bagian 3 menguraikan metode penelitian yang digunakan, bagian 4 menyampaikan hasil penelitian yang telah diuji secara empiris hubungan antara globalisasi ekonomi dengan tingkat kesenjangan pendapatan di negara-negara objek penelitian. Bagian akhir adalah kesimpulan hasil penelitian.

\section{Dampak globalisasi ekonomi} terhadap suatu wilayah masih menjadi topik yang menarik untuk dikaji, adalah (Ezcurra dan Rodríguez-Pose, 2013) yang telah menguji hubungan globalisai ekonomi dan tingkat kesenjangan regional, dengan menggunakan data Cross-section di 47 negara secara panel menunjukkan hasil bahwa terdapat hubungan positif dan signifikan antara globalisasi ekonomi dengan tingkat kesenjangan regional, negara dengan tingkat integrasi ekonomi tinggi akan diikuti pula dengan tingginya tingkat ketimpangannya, disisi lain globalisai ekonomi berpengaruh besar terhadap negara dengan tingkat pendapatan menengah dan rendah. Disamping itu, secara empirik menunjukkan tingkat disparitas yang tinggi terjadi secara signifikan jika dibandingkan dengan negara dengan tingkat pendapatan tinggi. Varibel-variabel yang digunakan adalah KOF indeks globalisasi ekonomi, tingkat pendapatan per kapita, tingkat populasi penduduk, fraksionalisasi etnis, ukuran pemerintah dan dasar pemerintahan suatu negara.

Secara teoritis untuk menjelaskan tentang integrasi ekonomi di suatu wilayah dengan menggunakan teori New Economic Greograpy (NEG) pengembangan dari teori klasik, dengan meningkatnya perdagangan di dunia akan menyebabkan ongkos yang murah ini dikarenakan distribusi yang merata secara spasial antar negara sehingga assumsi yang digunakan adalah pasar kompetitif sempurna dengan skala ekonomi di tingkat regional. Disisi lain, Tori New Economic Greograpy (NEG) menjelaskan tentang 
kerangka pikir dari faktor penentu dari lokasi aktivitas ekonomi dinamis antar wilayah di suatu negara (Krugman, 1990). Implikasi teoritis, secara spasial selam 20 tahun terakhir menunjukkan adanya hasil yang berbeda secara fungsional maupun asumsi yang berbeda dari dampak integrasi perdagangan.

Beberapa model (Monfort dan Van Ypersele, 2003) serta (Paluzie, 2001)) menunjukan bahwa dampak integrasi perdagangan (globalisasi ekonomi) akan mengurangi tingkat disparitas ekonomi antar negara, namun disisi lain (Krugman \& Elizondo, 1996) menunjukan bahwa liberalisasi perdagangan akan berdampak positif terhadap tingkat ketimpangan pendapatan antar negara di suatu wilayah terentu. Sedangakan dampak dari integrasi ekonomi terhadap tingkat ketimpangan di suatu negara bisa di lihat hasil penelitian (Lipton \& Zhang, 2007; Zhang \& Kanbur, 2005) yang menyatakan bahwa tingkat liberalisasi perdagangan di Cina secara positif berdampak pada meningkatnya tingkat kesenjangan antar wilayah. Hal yang sama ditemukan pada penelitian di Meksiko (Faber, 2007) yangg menyatakan bahwa tingkat ketimpangan antara daerah meningkat sejalan dengan peningkatan perdagangan yang terbuka.

\section{METODE PENELITIAN}

Data yang digunakan adalah Pooled data negara-negara anggota ASEAN yang diteliti yaitu Kamboja, Indonesia, Laos, Malaysia, Thailand dan Vietnam pada periode waktu 2000 sampai dengan tahun 2012. Sumber data penelitian ini adalah dari WDI (World Development Indicators) dan Situs Bank dunia. Pendekatan yang digunakan pada penelitian ini adalah Pooled Least square (PLS), yaitu mengestimasi data panel dengan metode O1S. Model yang digunakan untuk menguji pengaruh globalasi ekonomi terhadap ketimpangan wilayah di ASEAN adalah merujuk model (Ezcurra \& Rodríguez-Pose, 2013) dengan spesifikasi sebagai berikut:

$$
\text { Gini }_{i t}=\alpha_{1}+\alpha_{2} \text { glob }_{i t}+\alpha_{3} D_{i t}+e_{i t}
$$

Dimana:

gini $=$ Tingkat Ketimpangan yang diukur dari Indeks Theil

glob $=$ KOF Indeks globalisasi ekonomi

$D \quad=$ Vektor variabel lain seperti tingkat pendapatan per kapita dan jumlah populasi

$\alpha \quad=$ Koefisien estimasi

$\mathrm{i}=$ Negara

$\mathrm{t} \quad=$ Tahun

$\mathrm{e}_{\mathrm{it}} \quad=$ Variabel gangguan 


\section{PEMBAHASAN}

Globalisai ekonomi yang terjadi di negara-negara ASEAN bisa ditunjukan dengan adanya KOF yaitu suatu indeks globalisai ekonomi yang dikembangkan oleh (Dreher, 2006), Pada tabel. 1. Menyajikan variabel actual flows dari globalisasi ekonomi seperti, Perdagangan, investasi langung dan surat berharga (stock), investasi portofolio dan pendapatan dari pembayaran warga negara asing. Sementara untuk komponen restrictions antar negara dari globalisai ini adalah hambatan impor, tingkat rata-rata tarif, pajak perdagangan internasional, dan sejumlah hambatan modal. Dengan menggunakan indikato KOF indeks globalisasi yang terdiri dari variabel tersebut telah menjawab adannya keraguan dari hubungan salah satu variabel variabel globalisasi ekonomi terhadap tingkat kesenjangan pendapatan. Adapun gambaran tingkat ketimpangan pendapatan yang terjadi di negara ASEAN terlihat dalam Gambar 3. Indek globalisasi menunjukkan perkembangan yang positif dengan median di ASEAN sebesar 54.77, dan pada scater plot menunjukkan bahwa Cambodia (49.04),Vietnam (48.58), dan Laos (27.7) masih memiliki nilai indeks di bawah median di ASEAN. Sedangkan Malaysia (79.55) menempati peringkat tertinggi yang diikuti oleh Thailand (65.34), Filipina (57.40) dan Indonesia (56.41).

Tabel 1. Komponen dari KOF Indeks Globalisasi Ekonomi

\begin{tabular}{ll}
\hline Indikator dan variabel & Weights (\%) \\
\hline i) $\quad$ Actual Flows & $(50 \%)$ \\
Trade (percent of GDP) & $(21 \%)$ \\
$\quad$ Foreign Direct Investment, stocks (percent of GDP) & $(27 \%)$ \\
Portfolio Investment (percent of GDP) & $(24 \%)$ \\
Income Payments to Foreign Nationals (percent of GDP) & $(27 \%)$ \\
ii) Restrictions & $(50 \%)$ \\
Hidden Import Barriers & $(24 \%)$ \\
Mean Tariff Rate & $(28 \%)$ \\
Taxes on International Trade (percent of current revenue) & $(26 \%)$ \\
Capital Account Restrictions & $(22 \%)$
\end{tabular}

Sumber: http://globalization.kof.ethz.ch/ 


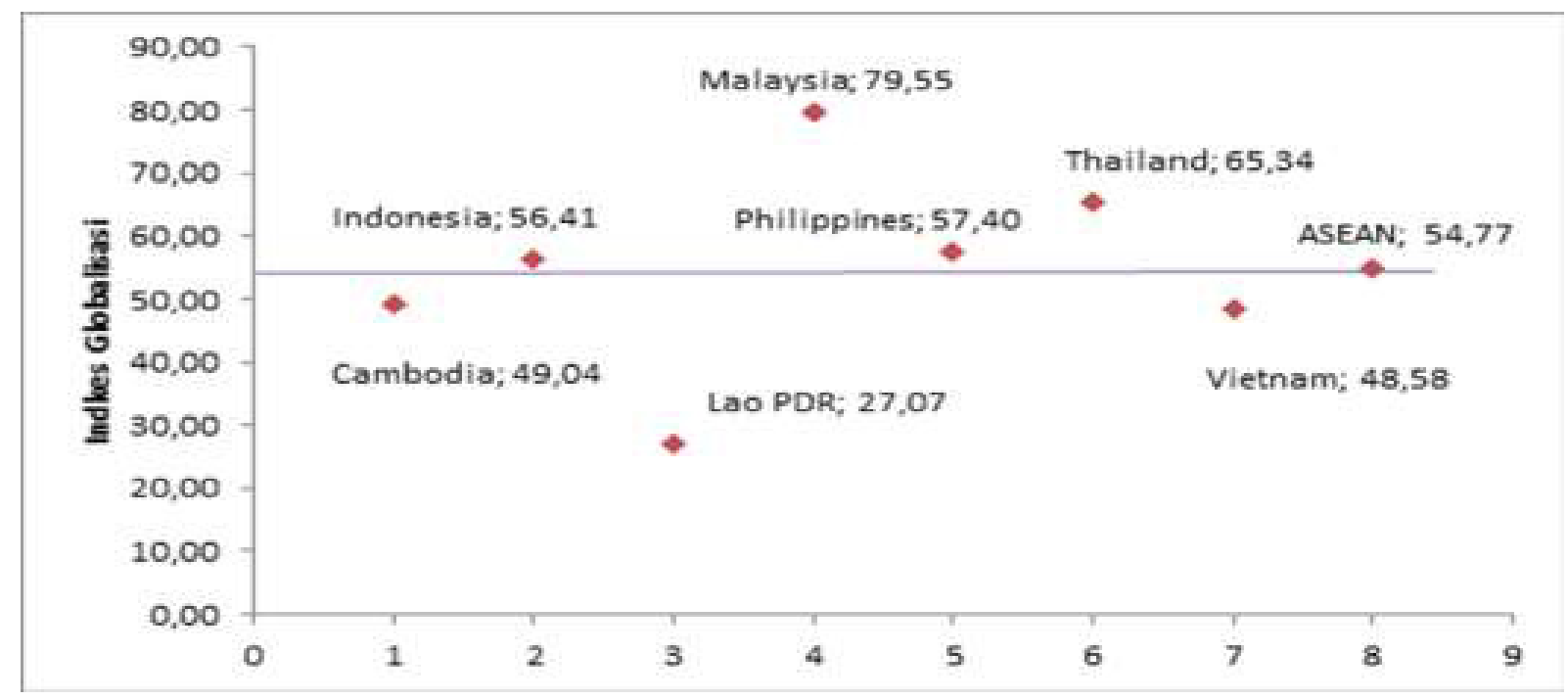

Gambar 3. Perkembangan Indeks Globalisasi pada beberapa negara anggota ASEAN 2011 Sumber: http://globalization.kof.ethz.ch/(data diolah)

Disisi lain, tingkat ketimpangan pendapatan yang diukur dari indek gini regional di ASEAN menunjukkan penurunan, hal ini bisa terlihat dari nilai indek gini rasio di Kawasan ASEAN adalah sebesar 0.41 pada tahun 2002 menjadi 0.37 pada tahhun 2012. Artinya adalah tingkat ketimpangan menurun antar negara-negara yang diteliti di kawasan ASEAN dan masuk kategori ketimpangan rendah yaitu antara 0,3 sampai

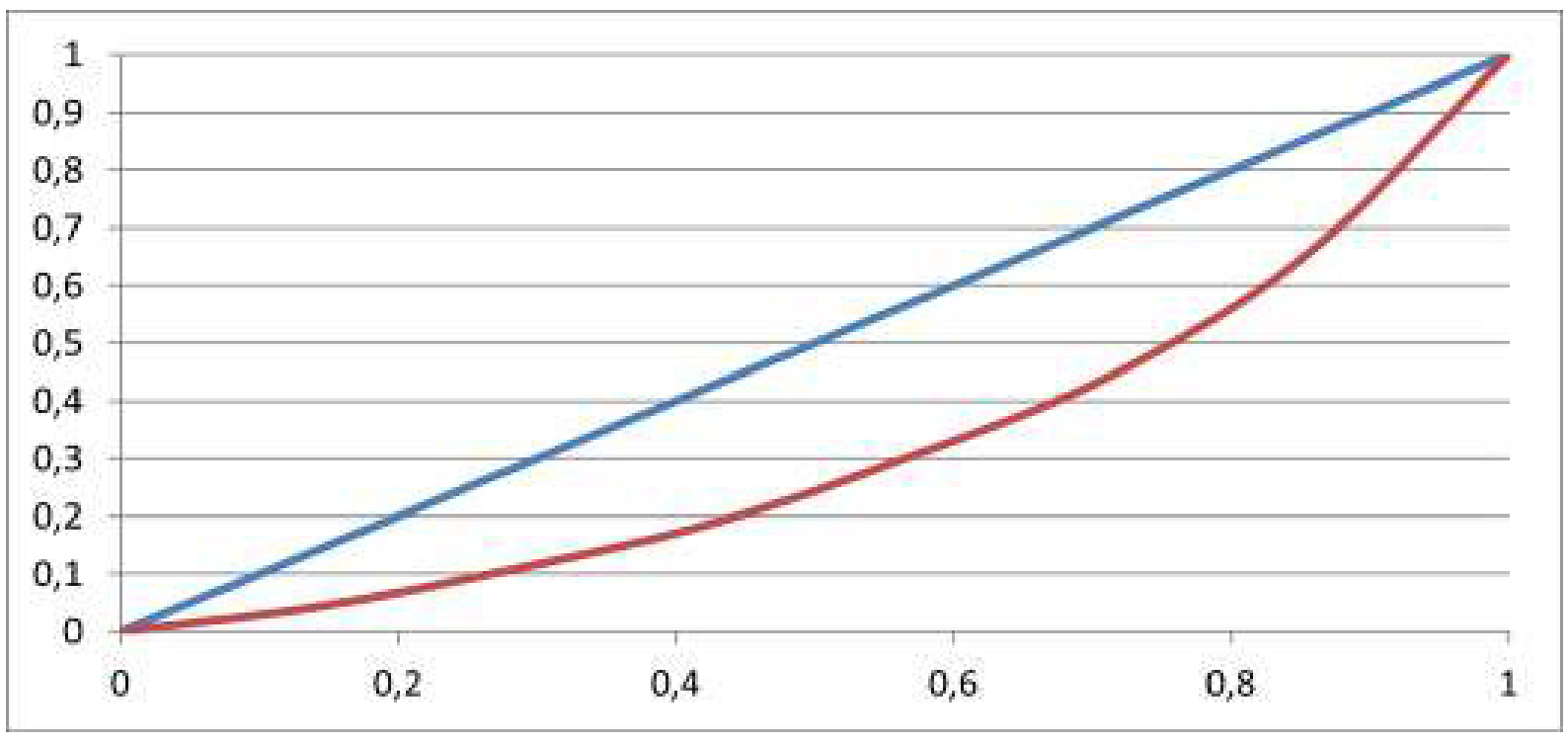

Gambar 4. Kurva lorenz tingkat ketimpangan pada tahun 2012 di ASEAN Sumber: Hasil Pengolahan 
0,5. Hal ini bisa ditunjukkan pada Gambar 4. terkait kurva Lorenz yaitu kurva yang memberikan gambaran presentase penduduk yang menerima total pendapatan atau pengeluaran.

Tingkat kemerataan menurut Bank Dunia (dilihat dari persebaran atau distibusi pendapatan pada kelompok penduduk) dibagi menjadi 3 yaitu $40 \%$ pertama kelompok kurang beruntug, 40\% kedua kelompok menengah dan 20\% kelompok kaya. Pada kurva Lorenz semakin mendekati nol atau garis diagonal maka distribusi pendapatan yang diterima hampir sama dengan banyak penduduk, artinya pendapatan semakin merata.

Sementara untuk hasil estimasi model penelitian pengaruh globalisasi ekonomi terhadap tingkat ketimpangan pendapatan di negara-negara ASEAN yang menjadi pengamatan bisa diperlihatkan pada Tabel 2, penelitian ini dibagi menjadi tiga model penelitian sebagai berikut: Model 1 merupakan estimasi hubungan antara variabel jumlah penduduk dan goblalisasi ekonomi terhadap tingkat ketimpangan. Untuk melihat apakah model estimasi tersebut sahih atau tidak dan baik dari suatu

Tabel 2 Hasil Estimasi Regresi Pooled Data (Tingkat Ketimpangan)

\begin{tabular}{llll}
\hline & Model 1 & Model 2 & Model 3 \\
\hline Pop & -1.054 & -0.983 & -0.985 \\
Glob & $(17.27)^{* *}$ & $(33.17)^{* *}$ & $(33.32)^{* *}$ \\
& 1.924 & -0.036 & -0.017 \\
Gdpc & $(9.02)^{* *}$ & $(0.23)$ & $(0.11)$ \\
& & 1.020 & -3.209 \\
gdpc2 & & $(16.47)^{* *}$ & $(0.98)$ \\
& & & 2.110 \\
cons & & & $(1.29)$ \\
& -1.303 & -1.854 & -1.849 \\
$R^{2}$ & $(4.11)^{* *}$ & $(11.90)^{* *}$ & $(11.90)^{* *}$ \\
$N$ & 0.79 & 0.95 & 0.95 \\
\hline & 84 & 84 & 84 \\
\hline
\end{tabular}


model salah satunya dapat dilihat dari nilai $\mathrm{R}^{2}$. Hasil regresi di atas menunjukkan bahwa koefisien determinasi $\left(\mathrm{R}^{2}\right)$ sebesar 0.79 artinya variasi dalam variabel independen dapat dijelaskan sebesar 79\%. Sementara untuk melihat pengaruh variabel independen terhadap variabel dependen secara parsial sekaligus untuk menguji hipotesis yang didugakan. Hasil uji menunjukkan bahwa variabel jumlah penduduk berpengaruh negatif signifikan dengan tingkat kepercayaan $99 \%$ terhadap tingkat ketimpangan pendapatan di Kawasan ASEAN, dimana ketika jumlah penduduk meningkat sebesar $1 \%$ maka tingkat ketimpangan pendapatan akan turun sebesar 1,05\%. Sedangkan globalisasi ekonomi berpengaruh positif dan signifikan terhadap tingkat ketimpangan pendapatan di negara ASEAN, dimana ketika globalisasi meningkat sebesar $1 \%$ maka tingkat ketimpangan pendapatan akan meningkat pula sebesar 1,92\%.

Model 2 merupakan estimasi hubungan antara variabel jumlah penduduk goblalisasi ekonomi dan tingkat pendapatan perkapita terhadap tingkat ketimpangan. Untuk melihat apakah model estimasi tersebut sahih atau tidak dan baik dari suatu model salah satunya dapat dilihat dari nilai $\mathrm{R}^{2}$. Hasil regresi di atas menunjukkan bahwa koefisien determinasi $\left(\mathrm{R}^{2}\right)$ sebesar 0.95 artinya variasi dalam variabel independen dapat dijelaskan sebesar 95\%. Hasil uji parsial menunjukkan bahwa dengan tingkat kepercayaan $99 \%$ variabel jumlah penduduk berpengaruh negatif signifikan terhadap tingkat ketimpangan pendapatan di Kawasan ASEAN, dimana ketika jumlah penduduk meningkat sebesar $1 \%$ maka tingkat ketimpangan pendapatan akan turun sebesar $0.983 \%$. Sedangkan tingkat pendapatan per kapita berpengaruh positif dan signifikan terhadap tingkat ketimpangan pendapatan di negara ASEAN, dimana ketika pendapatan per kapita meningkat sebesar $1 \%$ maka tingkat ketimpangan pendapatan akan meningkat pula sebesar $1.02 \%$. Namun hasil yang berbeda pada variabel globalisasi yang menunjukkan pengaruh yang tidak signifikan terhadap tingkat ketimpangan di negara ASEAN.

Model 3 merupakan estimasi hubungan antara variabel jumlah penduduk goblalisasi ekonomi dan square tingkat pendapatan per kapita dan pendapatan per kapita terhadap tingkat ketimpangan. Meskipun hasil estimasi menunjukkan koefisien determinasi $\left(\mathrm{R}^{2}\right)$ sebesar 0.95 artinya variasi dalam variabel independen dapat dijelaskan sebesar 95\%. Namun Hasil uji parsial menunjukkan bahwa dengan 
tingkat kepercayaan $99 \%$ hanya variabel jumlah penduduk berpengaruh negatif signifikan terhadap tingkat ketimpangan pendapatan di Kawasan ASEAN, dimana ketika jumlah penduduk meningkat sebesar $1 \%$ maka tingkat ketimpangan pendapatan akan turun sebesar $0.983 \%$. Sedangkan variabel lain yang dimasukkan tidak berpengaruh signifikan terhadap ketimpangan pendapatan di negara ASEAN.

\section{KESIMPULAN DAN REKOMENDASI}

Globalisasi ekonomi tidak bisa lagi dihindari oleh negara-negara di kawasan ASEAN, terlebih lagi dengan adanya kesepakatan bersama membentuk adanya Masyarakat Ekonomi ASEAN pada tahun 2015, artinya sudah tidak ada lagi jarak antar negara baik dalam bidang memasarkan dan proses produksi, arus barang dan jasa, ketrampilan (skill), dan arus bebas modal yang masuk antar negara. Disisi lain, dampak yang terjadi dengan adanya globalisasi ekonomi ini adalah munculnya tingkat kesenjangan baik dalam bidang ekonomi, sosial politik dan bidang lainnya. Hal ini lah yang masih menjadi issu menarik untuk dikaji dan dibahas terkait kontradiksi dampak dari globalisasi terhadap tingkat ketimpangan wilayah.
Makalah ini menguji dengan 3 hasil model penelitian dengan hasil yang cukup menarik dimana terdapat perbedaan hubungan antara globalisasi ekonomi dan tingkat kesenjangan. Hanya model 1 yang menyatakan hubungan positif dan signifikan, hal ini sesuai dengan penelitian dari Ezcurra (2013) namun disisi lain, model 2 dan 3 menunjukkan tidak terdapat hubungan antara globalisasi dengan tingkat kesenjangan wilayah, hasil ini sesuai dengan penelitian yang dilakukan oleh Milanovic (2005). Sedangkan variabel jumlah penduduk berpengaruh negatif dan signifikan terhadap tingkat ketimpangan dan tingkat pendapatan per kapita berpengaruh positif dan signifikan.

Akhinya, rekomendasi penelitian selanjutnya adalah perlu dimasukkan variabel-variabel lain seperti tingkat fraksionalisai Etnik, dominasi agama, ukuran negara, sistem pemerintahan dan variabel lain ke dalam model determinan tingkat kesenjangan wilayah. Disamping itu penggunaan metode analisi lain yang bisa digunakan untuk menjawab tujuan penelitian yang disusun.

\section{DAFTAR PUSTAKA}

Austria, M. S. (2012). Moving Towards an ASEAN Economic Community. East Asia, 29(2), 141-156. 
Dreher, A. (2006). Does globalization affect growth? Evidence from a new index of globalization. Applied Economics, 38(2000), 1091-1110.

Dreher, A., Gaston, N., \& Martens, P. (2008). Measuring Globalisation: Gauging Its Consequences. Journal of Economic Literature (Vol. 47). New York, NY: Springer New York.

Ezcurra, R., \& Rodríguez-Pose, A. (2013). Does Economic Globalization affect Regional Inequality? A Cross-country Analysis. World Development, 52, 92103.

Faber, B. (2007). Towards the spatial patterns of sectoral adjustments to trade liberalisation: The case of NAFTA in Mexico. Growth and Change, 38(4), 567-594.

Krugman, P. (1990). Increasing Returns and Economic Geography. Journal of Political Economy, 99(3), 483-499. Retrieved from

Krugman, P., \& Elizondo, R. L. (1996). Trade Policy and the Third World Metropolis. Journal of Development Economics, 49(1), 137-150.

Lipton, M., \& Zhang, Q. (2007). Reducing Inequality and Poverty During Liberalisation in China/ : Rural and Agricultural Experiences and Policy Options.

Monfort, Philippe and Van Ypersele, Tanguy, Integration, Regional Agglomeration and International Trade (February 2003).
Paluzie, E. (2001). Trade policy and regional inequalities*. Papers in Regional Science, 80(1), 67-85.

Wells, R. (2006). Education's effect on income inequality: an economic globalisation perspective. Globalisation, Societies and Education, 4(3), 371-391.

Zhang, X., \& Kanbur, R. (2005). Spatial inequality in education and health care in China. China Economic Review, 16(2), 189-204. 
